\title{
MERCOSUL: ANÁLISE DOS CUSTOS E BENEFÍCIOS NO PRIMEIRO QUARTEL DE SÉCULO DA INTEGRAÇ̃̃O
}

\section{MERCOSUR: ANÁLISIS DE COSTOS Y BENEFICIOS EN EL PRIMER CUARTO DEL SIGLO DE LA INTEGRACIÓN}

Geziela Iensue

Resumo: Atualmente, a tônica das análises dos processos integrativos centra-se numa questão de resultados. Estas se pautam em indagações relacionadas aos custos e benefícios frente aos modelos de exercícios integrativos adotados, sendo a "empiria" o que se destaca, ou seja, em que medida determinada estratégia de integração pode ser eficiente, ou se são suportáveis os possiveis efeitos indesejados de sua aplicação. Entretanto, tais análises meramente de caráter operativo ou não operativo tendem a tangenciar os efeitos negativos ou disfuncionais sobre o social, bem como restringem a "ideia" social a um só componente, qual seja, o "mercado". O presente artigo busca apresentar um panorama do processo integrativo do MERCOSUL, ao longo dos seus vinte e cinco anos de existência, com vistas a identificar e avaliar as possíveis principais questões de caráter econômico, jurídico, político e social a desafiar o avanço do processo de integração regional. Para tanto, apresenta uma breve explanação historiográfica das conjunturas e criação das principais instituições mercosulinas durante o período em comento. Ademais, desenvolve uma análise econômica dos níveis de integração regional, enfatizando o atual estágio integrativo do MERCOSUL, isto é, de união aduaneira imperfeita. Além disso, empreende uma análise quanto à (des)necessidade da institucionalidade no âmbito do presente exercício integrativo regional. Conclusivamente, sustenta que a condição fundamental para superar as barreiras à efetiva integração e promoção de avanços, reside na concepção de que integração deve ser encarada como um jogo de soma positiva, onde todos os participantes - Estados, agentes econômicos e cidadãos vislumbrem maiores vantagens na participação ao invés da adoção de medidas isoladas. O processo integrativo regional deve ser um projeto de

\footnotetext{
* Professora voluntária da disciplina Direito da Integração Regional da Universidade Federal de Mato Grosso do Sul - UFMS.. E-mail: igeziela@gmail.com
} 
garantia de paz e desenvolvimento aos Estados Partes.

Resumen: Actualmente, el tono del análisis de los procesos de integración se centra en una pregunta de los resultados. Estos son guiadas en las cuestiones relacionadas con los costos y los beneficios en comparación con los modelos de ejercicios de integración adoptadas, y el "empírica" lo que más destaca, es decir, en qué medida determinada estrategia de integración pueden ser eficaces o son efectos no deseados posibles soportables de su aplicación. Sin embargo, este tipo de análisis meramente operativo o no operativo carácter tienden a tangente efectos negativos o disfuncionales en lo social y restringir la "idea" social a un solo componente, a saber, el "mercado". Este artículo busca presentar una visión general del proceso de integración del MERCOSUR, más de veinte y cinco años de existencia, con el fin de identificar y evaluar las posibles cuestiones importantes de la vida económica, jurídica, política y social para desafiar el progreso del proceso de la integración regional. Se presenta una breve explicación de situaciones historiográficas y la creación de las principales instituciones mercosureñas durante el periodo en discusión. Además, se desarrolla un análisis económico de los niveles de integración regional, con énfasis en la etapa de integración actual del MERCOSUR, es decir, la unión aduanera imperfecta. Por otra parte, se lleva a cabo un análisis sobre la (des) necesidad del marco institucional en virtud de este ejercicio de integración regional. En conclusión, sostiene que la condición fundamental para superar las barreras a la integración y la promoción del progreso eficaz radica en la idea de que la integración debe ser visto como un juego de suma positiva, donde todos los participantes - Unidos, agentes económicos $y$ los ciudadanos - prevén importantes ventajas la participación en lugar de adoptar medidas separadas. El proceso de integración regional debe ser una garantía del proyecto de paz y el desarrollo de los Estados Partes.

Palavras-chave: MERCOSUL, 25 anos, Integração

Palabras clave: MERCOSUR, 25 años, Integración

\section{INTRODUÇÃO}

"Es una idea grandiosa pretender formar de todo el Mundo Nuevo una sola nación con un solo vínculo que ligue sus partes entre sí y con el todo" (Simón Bolívar, trecho da célebre Carta de Jamaica - 1815).

As comemorações, ao se saber apreendê-las, podem constituir conjunturas férteis para a reflexão histórica e para os exercícios prospectivos. Por muitos motivos, os 25 anos da assinatura do Tratado de Assunção que se cumpriram em 26 de março de 2016, podem 
configurar uma ocasião propicia a essa perspectiva de aportes.

A partir de uma visão histórica do MERCOSUL nestes 25 anos, se buscará analisar o atual estágio da integração regional, notadamente, a evolução e perspectivas da união aduaneira parcial ou imperfeita, no marco de suas principais polêmicas, colocando em tensão alguns temas polêmicos, tais como, a evolução do quadro comercial e econômico do bloco, o tratamento das assimetrias, os itinerários da agenda externa comum, aprofundar a articulação produtiva na escala regional, a dimensão institucional e política do processo com maior participação dos cidadãos dos Estados Partes.

Neste contexto, evidenciar-se-á que a categoria "integração" que ainda hoje se faz presente no imaginário latino-americano, representa a tentativa de superação da "colonialidade" preservada ao longo dos séculos, sob a perspectiva eurocêntrica de dominação e exploração no continente instalada desde os tempos coloniais.

Em seguida, tratar-se-á do estágio de união aduaneira a partir das contribuições da análise econômica do fenômeno em questão. $\mathrm{O}$ instrumental teórico básico que será utilizado para tal análise baseiase nos estudos desenvolvidos pela literatura econômica especializada quanto aos custos e benefícios do processo de integração regional. A partir desse conjunto de estudos referenciais, o presente artigo buscará apreciar alguns aspectos relevantes da experiência atual com integração do MERCOSUL, de uma união aduaneiro imperfeita ou parcial.

Posteriormente, buscar-se-á apresentar a complexa inter-relação entre as conjunturas históricas regionais e a evolução institucional do MERCOSUL durante os seus primeiros cinco lustros, enfatizando a (des)necessidade da dimensão institucional e política do processo.

Longe de pretender esgotar o tema, sustentar-se-á a relevância do alinhamento das abordagens conceituais à prática dos processos políticos engendrados no bloco, assim como as relações internacionais de cooperação, a integração não pode ser compreendida como mera questão técnica ou adstrita aos desígnios macroeconômicos, posto que, se encontra vulnerável aos condicionantes do poder e à vontade política das gestões governamentais.

Destacar-se-á que, a despeito dos avanços econômicos obtidos pelo bloco regional MERCOSUL o fenômeno de exclusão social, ainda se faz evidente, em todos os seus Estados Partes o que denota a importância do delineamento de mecanismos capazes de promover o acesso e distribuição equitativos dos bens e oportunidades no âmbito regional.

Por fim, em item conclusivo, procurar-se-á sustentar que nenhuma das temáticas da nova agenda MERCOSUL encontra-se isenta de problemas e contradições. Certamente não se revela possível sustentar uma perfeita integração sem que haja transformações ainda que graduais, tampouco desprovidas de conflitos. Os obstáculos a serem 
transpostos não se mostram pequenos, portanto, ao largo de visões voluntaristas ou ingênuas a conjuntura atual revela-se, mais uma vez, como uma oportunidade que não se deve desperdiçar rumo à solidez do futuro do bloco.

\section{BREVE ESCORÇO HISTÓRICO DO MERCOSUL EM SEUS 25 ANOS}

A temática da integração, em termos de América Latina, remonta a um passado distante situado no repertório das grandes utopias libertárias, desde Simon Bolívar ${ }^{1}$, e posteriormente, na década de 1920 com Mariátegui La Chira². Tais concepções libertárias baseavam-se no combate aos efeitos perniciosos da dominação exercida pelo poder colonial, especialmente, a destruição da identidade coletiva nativa e o subjugar dos povos aborígenes por meio da unidade latino-americana ${ }^{3}$.

Tal movimento de afirmação dos países americanos frente às metrópoles europeias ocorreu não somente por meio de ações militares, mas mediante Declarações, Conferências e manifestações diplomáticas. Por conseguinte, resulta de um movimento regional político com desdobramentos culturais e jurídicos sobre as ideias e as ações dos Estados da região ${ }^{4}$.

Neste contexto, evidencia-se que a categoria "integração" que se faz presente ainda hoje no imaginário latino-americano, representa a tentativa de superação dessa "colonialidade" preservada ao longo dos séculos sob a perspectiva eurocêntrica moderna aqui instalada desde a época colonial ${ }^{5}$.

O eixo central para compreender a formação do bloco regional MERCOSUL está intrinsecamente vinculado à percepção do antagonismo, primeiro entre Espanha-Portugal, e posteriormente entre dois polos "hegemônicos". Em termos históricos, ao longo dos séculos, é possível distinguir no território da Bacia do Rio da Prata, dois polos, um dos quais, composto pelos países "hegemônicos" Argentina e Brasil, e outro integrado por três países "satélites", Uruguai, Paraguai e Bolívia.

Pode-se considerar que, a grande maioria dos conflitos ocorridos na

\footnotetext{
1 A utopia da unidade latino-americana encontra, sem dúvida, sua maior expressão no pensamento e na obra de Bolívar, seu maior intento era, por meio de uma confederação de nações livres, "formar na América a maior nação do mundo menos por sua extensão e riqueza que por sua liberdade e glória”. BOLÍVAR, Simón apud MARIÁTEGUI, José Carlos. Siete ensayos de interpretación de la realidad peruana. Caracas: Fundación Biblioteca Ayacucho, 2007, p. 15. Francisco de Miranda na Venezuela, Joaquim José da Silva Xavier no Brasil; Rivadavia, José de San Martín, Mariano Moreno, Bernardo Monteagudo, e vários outros também foram líderes dos movimentos de emancipação.

2 MARIÁTEGUI, José Carlos, op. cit, p. 161-180; p. 243.

3 A partir de 1810 começam as guerras pela independência das colônias frente às metrópoles europeias.

4 ARBUET-VIGNALI, 2004, p. 199.

5 SÁNCHEZ, 2004, p. 21.
} 
região tem haver com os significados desta dualidade, particularmente com a dialética gerada pelas aspirações dos Estados hegemônicos - precedidas por seus conquistadores coloniais, Espanha e Portugal - e pelas restritas ações adotadas pelos outros três Estados "menores", que buscavam afirmar os seus interesses no âmbito das relações assimétricas regionais ${ }^{6}$.

Ao analisar alguns pontos de conflito na região percebe-se, em grande medida, a influência da inter-relação entre os dois polos referidos. Exemplificativamente, a livre navegação pelos rios interiores, confirmada pela sangrenta Guerra da Tríplice Aliança (1865-1870); a paulatina formação dos Estados nacionais no território da Bacia do Rio da Prata, com a delimitação turbulenta de seus limites territoriais; a resolução do predomínio do eixo transversal ou longitudinal ${ }^{7}$; as grandes disputas em torno do aproveitamento do potencial hidroelétrico da região; o delineamento dos denominados "corredores de exportação" e o orientação dos países até o Atlântico ou até o Pacífico ${ }^{8}$.

Mencionam-se ainda, as controvérsias mais recentes, sobre as estratégias voltadas a impulsionar o aproveitamento e conectividade energéticos por meio do gás natural e do petróleo, assim como o envolvimento, em especial, pelo Brasil em programas de geração de biocombustíveis ou de vias alternativas de energia, dentre outras que se podem citar.

Nota-se que, tal interação entre "hegemônicos" e "satélites", ao longo dos séculos, ora assumiu a lógica bélica da conquista militar, como na Guerra da Tríplice Aliança contra o Paraguai, ora o caminho das iniciativas diplomáticas e negociações bilaterais, especialmente, no trato dos assuntos envolvendo o aproveitamento energético dos rios internacionais. Não obstante, recentemente o conflito entre os países "hegemônicos" se traduz na tensão entre bilateralidade versus multilateralidade .

Por conseguinte, esta oposição que se inicia ainda no período colonial e se estende por todo século XIX e grande parte do século XX, adquire um perfil mais estruturado e consistente a partir da década de 1930, quando começa a denominada "era da geopolítica". Desde então, sob a égide do "paradigma do conflito" dá-se a disputa pela liderança hegemônica entre Brasil e Argentina, no que tange a consolidação dos domínios territoriais, produtivos e comerciais da região do cone $\mathrm{Sul}^{10}$.

Uma nota distintiva do exercício integrativo MERCOSUL é que

\footnotetext{
6 ALMEIDA, 1998, p. 12.

7 Transversal (favorável ao Brasil) e longitudinal (favorável à Argentina). Os antagonismos geopolíticos fundamentais centram-se em torno da oposição Atlântico versus Pacífico e Amazonas versus Rio da Prata.

8 MONIZ BANDEIRA, 2004, p. 22-23.

9 O Brasil tendeu a adotar, quer por motivos históricos, geográficos ou políticos, o bilateralismo, ao passo que a Argentina, com menos êxito, buscou reivindicar em vários episódios os princípios multilaterais. MONIZ BANDEIRA, Antônio de Jesus. O eixo Argentina-Brasil. O processo de integração da América Latina. Brasília: Universidade de Brasília, 2004, p. 81.

10 ZEA, 1999 , p. 5.
} 
este constitui essencialmente um processo de aproximação de economias geograficamente próximas, com um histórico de transações mercantis e econômicas limitadas. Tal processo de aproximação é resultante de uma decisão política que coincidiu com a redemocratização de seus países integrantes.

Há uma história do MERCOSUL que antecede ao Tratado fundacional em 1991. Elencam-se as etapas prévias do regionalismo latino-americano impulsionado desde os anos $1950^{11}$ com os trabalhos da CEPAL e com a concretização das experiências com a Associação Latino-Americana do Livre Comércio (ALALC) em $1960^{12}$ e sua posterior conversão na Associação Latino- Americana de Integração (ALADI) na década de $1980^{13}$.

Digna de menção dentre os eventos que antecederam, especificamente, a criação do MERCOSUL, foi o estabelecimento da União Aduaneira Brasil-Argentina, já no ano de 1941. Para esse efeito, se constituiu uma Comissão Mista de Alto Nível presidida pelos Ministros das Relações Exteriores. Na mesma ocasião, se firmou a Declaração Conjunta sobre Política Nuclear, com o objetivo de cooperação bilateral nessa área com fins pacíficos.

Oambientemarcadopelacriseeconômicaeaondaderedemocratização no continente propiciou uma nova fase no relacionamento entre esses dois países, levando à superação da histórica rivalidade que obstaculizava a integração econômica e política entre os mesmos $^{14}$.

De certo modo, essa pré-histórica mercosulina está sintetizada na Declaração de Iguaçu, firmada entre os presidentes então em exercício, do Brasil, José Sarney e da Argentina, Raúl Alfonsín. O documento formulado em 30 de novembro de 1985 prefigurava um processo de integração bilateral entre esses dois países por meio de um conjunto de ações e negociações que, mais tarde, se desdobraria na iniciativa quadrilateral do MERCOSUL.

A Ata para a Integração Brasil-Argentina, firmada em 26 de julho de 1986, em Buenos Aires, estabeleceu o Programa de Integração e Cooperação Econômica (PICE), que marcou o inicio de uma complementação em matérias de produtos de capital e alimentos por meio da adoção de doze protocolos setoriais. No mesmo ano, em encontro ocorrido em Brasília, em 10 de dezembro, foi ampliado o Programa com a adoção de mais cinco novos Protocolos, e a subscrição da Ata de Amizade Argentino-Brasileira, Democracia, Paz e Desenvolvimento ${ }^{15}$.

11 Em 1950 e 1953 se propôs o pacto ABC entre Argentina, Brasil e Chile.

12 A Associação Latino-Americana de Livre Comércio - ALALC foi criada pelo Tratado de Montevidéu como uma organização institucional considerada primária e tradicional específica dos Tratados internacionais clássicos.

13 ARBUET-VIGNALI, 2004, p. 199.

14 CHIARELLI, 2004, p. 47-48.

15 Ainda em Buenos Aires, Argentina e Brasil, em julho de 1987 estenderam o Programa de Integração Bilateral, incorporando três novos Protocolos. 
Em 07 de abril de 1988, foi subscrita pelos presidentes da Argentina, do Brasil e do Uruguai, a Ata de Alvorada, pela qual se formalizou a participação do Uruguai no processo de integração, no que tange ao setor de transporte terrestre. Em 29 de novembro do mesmo ano, Brasil e Argentina celebram o Tratado de Integração, Cooperação e Desenvolvimento, o qual tem por finalidade constituir um mercado comum bilateral no prazo de dez anos ${ }^{16}$.

No âmbito ainda da ALADI, esse processo evolui dinamicamente e culmina, em 06 de julho de 1990, na Ata de Buenos Aires, a qual reduzia os prazos anteriormente previstos, e cujo objetivo era acelerar o programa de constituição de um mercado comum, por meio da redução geral de tarifas, linear e automática, assim como a eliminação de barreiras não tarifárias.

É o início das negociações que conduzirão ao MERCOSUL, criase o Grupo Mercado Comum, em julho de 1990, em Buenos Aires, formado por funcionários governamentais argentinos e brasileiros, com a incumbência de proposição e elaboração de medidas tendentes à conformação do Mercado Comum por meio da harmonização das políticas de ambos os países na área comercial, fiscal, monetária, industrial, agrícola e de transporte marítimo e terrestre ${ }^{17}$.

Em agosto de 1990, o então presidente, do Uruguai, Luis Alberto Lacalle, e do Paraguai, André Rodriguez, solicitam a entrada dos seus respectivos paises no Acordo que à época se encontrava na fase de elaboração. Finalmente, em 26 de março de 1994, em Assunção ${ }^{18}$, os presidentes da Argentina, Brasil, Paraguai e Uruguai firmaram o Tratado de Assunção com vistas à formação do Mercado Comum em 31 de dezembro de $1994^{19}$.

O referido documento que, entrou em vigor em 29 de novembro

16 Entre os anos de 1984 e 1989, firmaram-se entre o Brasil e a Argentina, 24 Protocolos bilaterais, aprofundando a nova política exterior das duas maiores econômica da América do Sul e regulamentando diversos assuntos em comum.

17 ALMEIDA, 1998, p. 43.

18 Segundo os entendimentos dos professores, Ekmekdjian, Gros Espiell e Margariños, quanto à natureza jurídica do Tratado de Assunção, este é, um dos Acordos Parciais de integração econômica regulados nos Capítulos II e IV do Tratado ALADI - Tratado de Montevidéu de 1980. ESPIELL, Héctor Gross. In: Temas de Integração com enfoques no MERCOSUL. São Paulo: LTr, 1997, p. 240-267; PIZZOLO, Calogero. Globalización y integración - ensayo de una teoría general. Buenos Aires: Ediar, 2002, p. 64).

19 Conforme o Capítulo II do Tratado de Assunção, a estrutura orgânica do MERCOSUL ficou constituída, para o período de transição que iria até 31.12.94, pelos seguintes órgãos: Conselho do Mercado Comum (CMC) e Grupo Mercado Comum (GMC). O anexo V do referido Tratado determinou que o GMC constituísse subgrupos de trabalho destinados à coordenação das políticas macroeconômicas e setoriais, que são os seguintes: assuntos comerciais, assuntos aduaneiros, normas técnicas, politica fiscal e monetária relacionada com o comercio, transporte terrestre, transporte marítimo, politica industrial e tecnológica, politica agrícola, politica energética e coordenação do politicas macroeconômicas. Estes subgrupos de trabalho foram substituídos por onde novos subgrupos: comunicação, mineração, regulamentos técnicos, assuntos financeiros, transporte e infraestrutura, meio ambiente, indústria, agricultura, energia, assuntos trabalhistas, emprego e seguridade social e saúde. 
de 1991 constitui a criação do Mercado Comum do Sul - MERCOSUL, e se encontra nos registros da ALADI como Acordo de Complementação n. 18. Por conseguinte, o MERCOSUL originou-se como consequência das negociações entre a Argentina e o Brasil, e se transformou em um empreendimento coletivo a partir do ingresso do Paraguai e do Uruguai ${ }^{20}$.

Tanto a nível nacional como internacional, os tempos eram de transformações e transcorriam com enorme velocidade, especialmente, após o fim da Guerra Fria e da queda do Muro de Berlim. Conforme afirma Eric Hobsbawn, "aproximava-se o fim do século curto"21. Posteriormente, a assinatura do Tratado de Assunção, forma firmados três protocolos adicionais: o Protocolo de Brasília, o Protocolo Adicional ao Tratado de Assunção sobre a Estrutura Institucional do MERCOSUL, denominado Protocolo de Ouro Preto, e o Protocolo de Olivos.

O Protocolo de Brasília, firmado em dezembro de 1991 e tendo entrado em vigor em 24 de abril de 1993, após a sua ratificação, estabelece a via arbitral para a Solução de Controvérsias no MERCOSUL. Dessa maneira, o Protocolo institui mecanismo ad hoc de solução arbitral dos conflitos comerciais entre os Estados-partes do bloco, lançando as bases para o funcionamento de um Tribunal Arbitral constituindo este a última instância, com decisões finais vinculantes.

Estabeleceu dois ritos de solução de controvérsias, numa primeira fase conciliatória, observa-se procedimento perante a Comissão de Comércio e do Grupo Comum ${ }^{22}$, por meio de negociações diretas, conforme a matéria em discussão. Caso essas negociações resultem frustradas ou a controvérsia seja solucionada apenas parcialmente, admite-se recurso ao juízo arbitral. Recorrendo ao procedimento arbitral, de caráter jurídico, é instaurado o Tribunal ad hoc composto por três árbitros que decidirão a controvérsia de acordo com o que dispõe o artigo 19 do Protocolo de Brasília ${ }^{23}$.

Entretanto, depois da aprovação do Protocolo de Ouro Preto, aprovado em 1994, pela Cúpula de Presidentes de Ouro Preto, se decidiu modificar a vigência restrita ao período de transição do Protocolo de

20 BIOCCA, 2001, p. 21-22.

21 HOBSBAWN, 1995, p. 10.

22 Caso a controvérsia seja submetida ao Grupo Mercado Comum, este atuará como mediador entre os Estados. Sua função é, ao final das negociações, apresentar propostas ou recomendações com o objetivo de finalizar o litigio.

23 Tal dispositivo dispõe que a decisão terá por base as disposições do Tratado de Assunção, os acordos celebrados no âmbito do mesmo, as Decisões do Conselho Mercado Comum, as Resoluções do Grupo Mercado Comum, bem como os princípios e disposições de direito internacional aplicáveis à matéria. A decisão n. 1/92 do Conselho do Mercado Comum estabelece um extenso programa de medidas, denominado "Cronograma de Las Leñas" com vistas ao cumprimento dos compromissos firmados no Tratado de Assunção. Durante reunião ocorrida em julho de 1992, foi firmado o Protocolo de Las Leñas de cooperação e assistência jurisdicional em matéria civil, comercial, trabalhista e administrativa (o documento dispõe a simplificação dos trâmites de cumprimento de cartas rogatórias, reconhecimento de sentenças e laudos arbitrais). PÉREZ OTERMIN apud PIZZOLO, Op. cit., 2002, p. 91. 
Brasília, complementado pelo Protocolo de Ouro Preto, que terá vigência até que se adote um sistema definitivo. Tal instrumento estabeleceu a personalidade jurídica internacional do bloco regional, cuja titularidade é exercida pelo Conselho do Mercado Comum ${ }^{24}$, assim como definiu a estrutura institucional do MERCOSUL, ademais determina o poder de decisão dos seus órgãos ${ }^{25}$.

Reconhece também, a obrigatoriedade de acatar as decisões de suas instituições, como fontes derivadas do direito da integração do MERCOSUL ${ }^{26}$, ao lado dos Tratados constitutivos como fontes originárias, além disso, estabelece o compromisso dos Estados-partes de adotar as medidas que sejam imprescindíveis à garantia do cumprimento das normas obrigatórias, o chamado princípio da observância.

Com a assinatura do Protocolo de Ouro Preto, o MERCOSUL passou a ser uma união aduaneira ${ }^{27}$, sendo estipulada uma Taxa Externa Comum - TEC, em relação a terceiros países, bem assim uma política tarifária comum aos membros do bloco regional ${ }^{28}$. Insta evidenciar que, $o$ Tratado de Assunção e seus acordos complementares ainda não lograram êxito quanto à criação de um genuíno mercado comum, assim, por ora, $o$ MERCOSUL constitui uma união aduaneira parcial ou imperfeita ${ }^{29}$.

Nessa toada, evidenciam-se a criação em 1992 da Comissão Sindical do MERCOSUL, a instituição, em junho de 1997 do Fórum Consultivo Econômico e Social, a aprovação do Protocolo de Ushuaia, em 24 de julho de 1998 firmando o compromisso democrático dos países-membros do MERCOSUL, Bolívia e Chile. Ademais, em 1999, foi criada a Comissão Sociolaboral, de composição tripartite por meio da Resolução n. 15 do Grupo Mercado Comum, por incumbência deste em parceria com o Conselho do Mercado Comum, elaborasse um plano de ação estratégico com vistas a alcançar os objetivos do Tratado de Assunção, o denominado Mandato de Assunção.

O Protocolo de Olivos, firmado em 18 de fevereiro de 2002, em Buenos Aires, é o protocolo mais recente, cuja vigência se iniciou em 2004. Dispõe sobre a solução de controvérsias no contexto mercosulino,

24 Segundo preconiza o artigo $8^{\circ}$, inciso III, do Protocolo de Ouro Preto. Ver ainda, sobre a personalidade jurídica do MERCOSUL, os artigos 34 a 36 do Protocolo de Ouro Preto.

25 A estrutura orgânica do MERCOSUL disposta no artigo $1^{\circ}$ do Protocolo de Ouro Preto é a seguinte: Conselho do Mercado Comum (CMC); Grupo Mercado Comum (GMC); Comissão de Comércio do Mercosul (CCM); Comissão Parlamentar Conjunta (CPC); Foro Consultivo Econômico Social (FCES) e a Secretaria Administrativa do Mercosul (SAM). MERCOSUL. Protocolo de Ouro Preto, assinado em Ouro Preto, Brasil, em 17 de dezembro de 1994.

26 As decisões do MERCOSUL se dividem em: Decisões emitidas pelo Conselho Mercado Comum (CMC), Resoluções do Grupo Mercado Comum (GMC) e as Normativas da Comissão de Comércio do MERCÓSUL (CCM).

27 Conforme estabelece o artigo XXIV, paragrafo $8^{\circ}$, inciso a, do GATT, união aduaneira significa a substituição de dois ou mais territórios aduaneiros por um só, o que acarreta uma diminuição de restrições aduaneiras nas trocas comerciais.

28 ALMEIDA, 1998, p. 47.

29 GINESTA, 1999, p. 91. 
seja entre particulares, seja entre Estados-partes. Para esse fim, institui a formação de Tribunais Arbitrais Ad hoc e a fundação de um Tribunal Permanente de Revisão, representa um aprofundamento do processo integrativo e maior aprimoramento do mecanismo de resolução de controvérsias. O Parlamento do MERCOSUL foi instituído em 06 de dezembro de 2006, substituindo a Comissão Parlamentar Conjunta (CPC), sendo o órgão, por excelência, representativo dos interesses dos cidadãos dos Estados-partes do bloco mercosulino ${ }^{30}$. Não tem competência legislativa, cabendo-lhe a atribuição de acompanhar a atuação dos demais órgãos do MERCOSUL ${ }^{31}$.

Em 2007, a Decisão n. 03/07 do CMC criou o Instituto Social do MERCOSUL (ISM) com a finalidade de aprofundar a dimensão social e fortalecer o processo de integração. O Instituto de Políticas Públicas em Direitos Humanos (IPPDH) é constituído em 2009, pela Decisão n. $14 / 09$, tendo por objetivos desenvolver atividades destinas a capacitar funcionários públicos, promover estudos e apoiar tecnicamente as autoridades e instituições de direitos humanos dos Estados-partes e dos Associados do MERCOSUL, assim como as coordenar políticas regionais em direitos humanos. Por meio da decisão n. 63/10 do Conselho do Mercado Comum (CMC) cria-se a figura do Alto Representante Geral do MERCOSUL, como órgão do Conselho e a Unidade de Apoio à Participação Social (UPS).

Cabe mencionar, por fim, a adesão da Venezuela por meio do Protocolo de Adesão da República Bolivariana da Venezuela ao MERCOSUL, firmado em 04 de julho de 2006 em Caracas. Durante a $48^{\circ}$ Cúpula do MERCOSUL, ocorrida em julho de 2015, em Brasília, a Bolívia em processo de adesão, uniu-se ao bloco por meio do Protocolo de Adesão do Estado Plurinacional da Bolívia ao MERCOSUL ${ }^{32}$.

30 O Parlamento do MERCOSUL é formado por parlamentares dos Estados-membros, escolhidos por critérios internos e atua em diferentes temáticas, segundo a competência de cada uma de suas dez Comissões Permanentes: Assuntos Jurídicos e Institucionais; Assuntos Econômicos, Financeiros, Fiscais e Monetários; Assuntos Internacionais, Inter-Regionais e de Planejamento Estratégico; Educação, Cultura, Ciência, Tecnologia e Esportes; Trabalho, Políticas de Emprego, Segurança Social e Economia Social; Desenvolvimento Regional Sustentável, Ordenamento Territorial, Habitação; Saúde, Meio Ambiente e Turismo; Cidadania e Direitos Humanos; Assuntos Interiores, Segurança e Defesa; Infra-Estrutura, Transportes, Recursos Energéticos, Agricultura, Pecuária e Pesca; Orçamento e Assuntos Internos. [acesso em: 15 de mar. de 2016 ]. Disponível em: < http://www.parlamentodelmercosur.org/ innovaportal/v/4300/2/parlasur/o-parlamento.html>

31 Conforme a matéria delibera via pareceres, anteprojetos e projetos de normas, recomendações, relatórios e disposições, por maioria simples, absoluta, qualificada, conforme estabelece o seu Regimento Interno. O Regimento Interno do MERCOSUL encontra-se. [acesso em 15 de mar. de 2016]. Disponível em: < http://www.parlamentodelmercosur.org/ innovaportal/file/4296/1/regimento-interno---pt.pdf>

32 Outros países integrantes da ALADI podem participar das reuniões do bloco, na qualidade de convidados, para tratar de assuntos de interesse comum, dispondo de direito de voz, mas não de voto. Integram o grupo de Estados-associados: Chile, Colômbia, Equador, Peru, Guiana e Suriname, sendo estes dois últimos os mais recentes. 
No próximo item, serão apresentadas as características dos diversos níveis de integração regional. Em seguida, far-se-á uma análise básica dos ganhos e perdas com um processo de integração aduaneira imperfeita em nível de MERCOSUL.

\section{ANÁLISE ECONÔMICA DO NÍVEL INTEGRATIVO UNIÃO ADUANEIRA IMPERFEITA MERCOSUL}

Antes de avançar na análise econômica da atual fase integrativa do MERCOSUL, é importante esclarecer o objeto de análise. Todavia, é importante ressaltar, o que já foi afirmado pelo economista norteamericano, Paul Krugman ${ }^{33}$ no que tange à teoria de integração, a "análise dos efeitos dos acordos de preferências comerciais é objeto de uma literatura enorme e intrincada" (KRUGMAN; VENABLES, p. 959).

De fato, como se verá, o presente objeto de análise é cambiante e dinâmico, assim variados modelos teóricos podem levar a recomendações muito diversas de políticas.

A iniciativa pioneira dos países centro-americanos, na segunda metadedo século XX, em buscar no tratamento preferencial o fundamento para promover um processo de industrialização, influenciado pela iniciativa europeia - a Leste ${ }^{34}$ e a Oeste (Tratado de Roma, 1957), foi seguida por diversos documentos e compromissos formais de integração pelos diversos conjuntos de países latino-americanos.

Os acordos preferenciais entre dois ou mais países podem assumir diversas formas. Em geral esses variados formatos são apresentados em níveis subsequentes de graus de integração regional, sendo que cada nível corresponde a todo o anterior, acrescido de alguns elementos.

O nível mais básico é o de um acordo de preferências comerciais. Dois ou mais países podem decidir incrementar o potencial de comércio entre eles e para tanto firmam acordo de tratamento preferencial. Assim, um produto proveniente de um país $\mathrm{A}$, ao adentrar o país $\mathrm{B}$, conduzirá o fiscal da aduana a adotar um procedimento diferenciado, específico.

$\mathrm{O}$ acordo preferencial, geralmente, apresenta três características. Primeira, ele compreende um número limitado de produtos e margens de preferência que nem sempre alcançam $100 \%$ da alíquota de imposto de importação. A segunda característica é que esse acordo não demanda proximidade geográfica entre os Estados signatários. A terceira é que ele não pressupõe políticas coordenadas entre os países, resume-se à concessão de menores alíquotas de imposto de importação no comércio entre os países participantes.

Quando dois ou mais países resolvem diminuir ou eliminar as

33 Laureado com o Premio Nobel em Economia no ano de 2008 pela sua analise dos padrões comerciais e áreas de atividade econômica.

34 COMECON, 1949. 
barreiras comerciais entre si, está a se tratar de um estágio mais avançado de preferências comerciais, denominado Área de livre-comércio. Neste nível, o acesso aos produtos oriundos de um dos países participantes ao mercado dos demais é quase livre ou livre, sendo essencial identificar no fluxo de comércio, àquelas mercadorias que foram produzidas efetivamente no país associado, há necessidade, portanto, da adoção de "regra de origem" e de coordenação de políticas cambiais ${ }^{35}$.

No que diz respeito ao nível de integração caracterizado como uma união aduaneira, o que o distingue do anterior é a adoção de uma política externa comum por parte dos Estados participantes, estes definem conjuntamente sua política em relação ao tratamento a ser concedido às mercadorias provenientes de fora da área. Os Estados definem em conjunto uma estrutura tarifária conjunta, a Tarifa Externa Comum (TEC). Por ser o MERCOSUL considerado atualmente uma união aduaneira (ainda que imperfeita ou parcial) uma análise mais detalhada de uma união aduaneira será objeto de consideração mais detalhada no presente item, após rápida apresentação das características dos demais níveis de integração.

O Mercado Comum é essencialmente um nível mais avançado em relação à união aduaneira, posto que, além da livre circulação de produtos, da adoção de uma tarifa externa comum, da coordenação de políticas fiscal, cambial e monetária, há plena mobilidade de fatores de produção entre os Estados-partes. Desse modo, demanda ajustes mais amplos na legislação correspondente em cada país integrante, assim como a criação de um aparato institucional comunitário ${ }^{36}$.

O passo seguinte na escala de níveis integrativos refere-se à união monetária, ou seja, a criação de uma moeda comum que substitua as moedas nacionais dos diversos Estados-participantes. A condição básica para existir uma moeda comum é existir um órgão emissor regional, um Banco Central regional autônomo, independente e livre das influências políticas por parte dos Estados ou agentes econômicos. O exemplo mais significativo dos últimos anos é a implementação do euro, na União Europeia ${ }^{37}$.

A união política e econômica constitui dentre as diversas etapas do processo de integração, um passo ambicioso, tendo em vista que, nesse nível desaparecem os Estados-nação ${ }^{38}$ individuais, e ocorre a fusão dos diversos países em um mesmo ente federado. Constituem exemplos, os processos de formação da Alemanha e da Itália, durante a segunda metade do século XIX ${ }^{39}$.

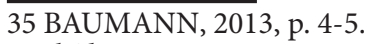

36 Ibíd.

37 Destaca-se que, o euro constitui exemplo de moeda emitida e corrente de aceitação ampla, mas sem uma base geográfica específica definida como origem.

38 No sentido empregado por Hobsbawn. HOBSBAWN, Eric. Nações e nacionalismo desde 1780. São Paulo: Paz e Terra, 1990.

39 PEREIRA DOS SANTOS, 1999, p. 25. 
Vistos os variados tipos ou níveis do processo integrativo, faz-se necessária a contextualização quanto às premissas de algumas teorias econômicas, tidas como fundamentais pela literatura econômica, no que tange à análise de custos e benefícios derivados do nível ou estágio integrativo união aduaneira.

A proposição de Jacob Viner formulada na década de 1950 influenciou fortemente, desde então, as análises realizadas pelos economistas no tocante aos efeitos derivados de um processo de integração. Antes da feitura de sua análise os teóricos da economia relutavam em admitir que a união aduaneira, sendo um passo no sentido da liberalização comercial poderia induzir elevação do nível de bem-estar social dos países partes no acordo ${ }^{40}$.

O modelo básico desenvolvido por Viner demonstrou que a união aduaneira combina elementos de comércio mais livre com elementos de maior proteção $0^{41}$. A criação de comércio representa um movimento na direção de uma situação de livre-comércio, já que implica uma transformação de fontes com elevados custos de abastecimento a outras de custas menos elevados, enquanto o desvio de comércio induz uma transformação nas compras do produtor de baixos custos para outro de custos mais elevados ${ }^{42}$.

Assim, predominarão os efeitos positivos da união, se os benefícios da criação do comércio superarem as perdas com os desvios do comércio. Consequentemente, uma redução discriminatória de barreiras comerciais - que beneficia alguns países parceiros - pode ser menor em termos de bem-estar social gerado, a uma diminuição não discriminatória ou abertura multilateral. Portanto, uma redução diferenciada de tarifas pode tanto melhorar a alocação de recursos e o nível de bem-estar social, dependendo das características de cada caso.

Estudos realizados por diversos autores demonstraram que existem vários outros elementos que afetam as previsões de benefícios ou custos, além dos conceitos desenvolvidos por Viner, de extensão do comércio produzido em contraposição ao comércio que é desviado. Meade (1951) argumentou que uma união aduaneira induzirá uma utilização eficiente de recursos se ela for composta por economias potencialmente similares ${ }^{43}$ ou potencialmente distintas ${ }^{44}$, posto que, entre economias potencialmente complementares há menos chances de ocorrer criação de comércio.

40 Cf. VINER, Jacob. The custos union issue. New York: Carnegie Endowment for Internation Peace, 1950.

41 A análise enfatiza os efeitos sobre a produção, derivados do comércio preferencial, medidos a partir dos conceitos, de criação e de desvio comercial.

42 VINER, 1950, p. 43.

43 As estruturas produtivas internas semelhantes.

44 Com vistas a existir divergências significativas nos custos comparativos entre os diversos produtores. 
Gehrels em 1956 e Lipsey evidenciaram em seus estudos, a possibilidade de haver efeitos positivos, mesmo diante da ausência de criação de comércio. Isso ocorreria quando os ganhos em no que tange ao consumo superam os efeitos negativos do desvio de comércio ${ }^{45}$. A formação de uma união aduaneira pode aumentar ao invés de diminuir o comércio com o país extrabloco, isso se dará caso as mercadorias produzidas neste forem complementares aos produtos cujo consumo aumentou com a união aduaneira ${ }^{46}$.

Estas análises sinalizam a importância do nível de tarifa externa comum a vigorar entre os Estados-parceiros ${ }^{47}$. Quanto mais próxima do nível de preços internacionais for essa tarifa comum, tanto mais positivo será o impacto na união aduaneira, pois quanto menor a barreira externa mais próxima os Estados envolvidos estarão de uma situação de livre-comércio ${ }^{48}$.

Desse modo, uma TEC considerada "ótima" em termos de teoria da proteção, é a que mantém as importações provenientes dos demais países no mesmo nível de antes da composição da União. Os primeiros anos de formação do MERCOSUL constitui um exemplo desse raciocínio ${ }^{49}$, em contraposição aos argumentos críticos ao exercício da integração $0^{50}$.

A resposta dos consumidores à redução dos preços de importação derivados da remoção da tarifa também precisa ser considerada quanto aos efeitos de uma união aduaneira. Segundo demonstrou o modelo de Gehrels (1956), o que permite verificar se um Estado experimentou benefícios com a união, está vinculada a constatação, se os ganhos obtidos pelos consumidores compensaram as perdas ocorridas na produção. Ademais, os ganhos e perdas com integração dependem ainda da análise de diversos outros elementos ${ }^{51}$.

$45 \mathrm{O}$ preço menor no mercado do país que concede a preferência estimula o consumo do produto importado, o que eleva o excedente do consumidor, independentemente do país de origem do produto.

46 LIPSEY, 1957, p. 40-46.

47 Kemp e Wan sugeriram em suas análises, a possibilidade de existir uma definição de tarifa comum "ideal" ou "ótima", do ponto de vista da união, capaz de proporcionar ganhos de bemestar derivados de uma melhora na relação entre preços de exportação e importação. Kemp \& Wan (1976).

48 Os efeitos positivos serão tanto mais elevados quanto maior o nível tarifário adotado antes da formação da união aduaneira. KEMP, M.; WANM H. An Elementary proposition concerning the formation of custos union. In: BHAGWATI, J. (Ed.) Selected readings in international trade. Massachussetts, C.A: The MIT Press, 1991.

49 Nesse período as importações totais dos países componentes do bloco cresceram a taxas sem precedentes, o que significa que o viés regional foi mais que compensado pela abertura multilateral dessas economias. As exportações intrarregionais cresceram em taxas expressivas, de 11\% em 1990 para 23\% em 1998. Em contraposição, o MERCOSUL sofreu retração pronunciada no comércio intrarregional no período entre 1998 e 2003. BAUMANN, Renato. Integração Regional: Teoria e Experiência Latino-Americana. 1. ed. Rio de Janeiro: LTC, 2013. 50 SINĆLAIR; HEFFERNAN, 1990; DEVLIN, 1997 apud BAUMANN, 2013, p. 32-34.

51 Exemplificativamente, as alterações das relações de troca (BALASSA, 1964; KEMP, 1969; FFRENCH-DAVIS, 1979), o papel das contas públicas (MUNDELL, 1964), o número de produtos e países (TINBERGEN, 1959; COLLIER, 1979; LIPSEY, 1960; BHAGWATI \& SRINIVASAN; 1984, a existência e efetividade de mecanismos compensatórios entre os 
O debate sobre as características e perspectivas positivas ou negativas derivadas da integração regional, tende ainda seguidamente, a negligenciar os efeitos monetários. A reflexão monetária da integração merece, portanto, consideração específica. Segundo a própria literatura de áreas monetárias ótimas (ÂMS), um nível maior de comércio entre os países favorece a unificação de moedas, dado que os custos de transação menores derivados de uma moeda única expandem a base de negócios ${ }^{52}$.

Resumidamente, o conjunto dessas análises aqui apresentadas revelou que a concessão de preferências a outros países exerce efeitos internos sobre o processo produtivo e a estrutura de consumo. Os impactos são diferentes entre os distintos setores produtivos, dada à semelhança ou complementaridade da estrutura produtiva do país parceiro com a do país concedente da preferência.

No que tange aos consumidores, o impacto é diferenciado em função da composição do conjunto de produtos consumidos por cada parcela da população, e da participação, nesse conjunto, dos produtos ofertados pelo país parceiro. Além disso, demonstram a importância do nível de tarifa externa comum a vigorar entre os Estados-parceiros. A reflexão monetária da integração merece também, no contexto uma atenção específica.

Neste contexto, insta evidenciar que a teoria de uniões aduaneiras passou adotar nova taxonomia para os acordos regionais, a partir de meados da década de 1980. Os avanços na teoria de comércio internacional, ao incorporar as possibilidades de economias de escala, concorrência imperfeita e a adoção de um "regionalismo aberto", culminaram na distinção entre os conceitos de "acordos de primeira geração" ${ }^{33}$ e os "acordos de nova geração" 54 .

A partir de alguns elementos indicados pelos estudos aqui analisados como fundamentais à compreensão dos efeitos derivados da integração regional, dentre os quais, os efeitos relacionados com o comércio e suas consequências sobre a estrutura produtiva e consumo, bem como os efeitos relacionados com a posição externa dos países, buscar-se-á analisar o estágio integrativo atual mercosulino, ou seja, de união aduaneira imperfeita.

Estados-parceiros, JOHNSON, 1965; COOPER \&MASSEL, 1965, o tamanho e o tipo de países adequados à formação do bloco; KRUGMAN, 1991; VENABLES, 2003, a existência de economias de escala, CORDEN, 1972; DEVLIN \& GIORDANO, 2004, estrutura de mercado e os efeitos monetários. Pereira dos Santos apresenta uma resenha contendo diversos exemplos de unificação monetária entre grupo de países. SANTOS, P.F. Pereira dos. União monetária: aspectos teóricos, experiências históricas e as perspectivas de implementação de uma moeda única no MERCOSUL. Brasília: UnB, 1999.

52 BAUMANN, 2013, p. 95.

53 Os acordos centrados somente em concessões comerciais e redução de barreiras.

54 Contemplam além da dimensão econômica outras dimensões políticas, tais como, meio ambiente, direitos trabalhistas e do consumidor, regulação da concorrência, dentre diversas outras. DEVLIN; GIORDANO, Paul. The old and new regionalismo: benefits, costs and implications for the FTAA. Cambrige, MA: Harvard University Press, 2004, p. 143-186. 
Quando da assinatura do Tratado de Assunção, em março de 1991, e a decisão pela adoção de uma tarifa externa comum, isso impôs às equipes negociadoras dos Estados- participantes o desafio de como delinear uma nova estrutura tarifária, comum aos quatro países ${ }^{55}$.

Os principais instrumentos da primeira etapa de aproximação entre Brasil e Argentina, entre os anos de 1986 a 1990, foram os 24 Protocolos firmados com vistas a dispor dos mecanismos à redução tarifária e a eliminação de barreiras não tarifárias. Dentre os Protocolos mencionados, cabe destacar o Protocolo de Bens de Capital, sendo este desde o início, considerado o "motor" do Programa de Integração.

A meta de se instituir um Mercado Comum do Cone Sul esteve presente desde o início das negociações entre a Argentina e o Brasil. Entretanto, o desenvolvimento inicial do MERCOSUL pode ser dividido em duas fases: a "fase de transição" (1991-1994) e, a partir de 01.01.1995, a existência do MERCOSUL como União Aduaneira.

A primeira fase, por sua vez, pode ser dividida em três etapas: i) a primeira, até o Cronograma de Las Leñas (julho de 1992), com um elenco preciso de tarefas para a "fase de transição"; ii) a segunda, quando os Estados participantes expressaram de maneira formal que a meta seria desta fase era a constituição de uma União Aduaneira e não um Mercado Comum ${ }^{56}$; iii) a terceira, até 31 de dezembro de 1994.

O processo de definição da Tarifa Externa Comum certamente representou um dos maiores desafios a serem enfrentados pelos paísesmembros com vistas à formação da união aduaneira. Entre outros obstáculos, havia diferenças expressivas na estrutura tarifária dos Estados envolvidos, além de problemas de desequilíbrio da balança comercial e de discrepâncias macroeconômicas ${ }^{57}$.

Paulatinamente desenvolveu-se um conhecimento crescente sobre o processo de integração, bem como o conhecimento recíproco entre os agentes econômicos, que gradativamente passam a tomar iniciativas quanto à continuidade e expansão dos acordos.

Assim, de uma lógica negociadora que inicialmente incentivava processos de especialização setorial e formas de integração intraatividades produtivas passa-se ao regime de desgravação geral, linear

55 Com a assinatura do Tratado, teve inicio o programa de liberalização comercial entre os países-participantes. Houve acordo quanto à redução semestral de $7 \%$ em todas as tarifas incidentes sobre produtos comercializados entre os quatro países, partindo de uma redução inicial de $47 \%$. Se, um produto tinha uma tarifa inicial de $20 \%$ (em $26 / 3 / 91)$ essa tarifa passaria a 10,6\%, em dezembro seria de 9,2\%, em junho de 1992 de 7,8\%, em dezembro do mesmo ano seria igual a 6,4\%, e assim sucessivamente. FLORENCIO, S.A.L.; ARAÚJO, E. H. F. MERCOSUL Hoje. São Paulo: Editora Alfa-Ômega, 1996, p. 18.

56 Diante disso, assuntos como circulação de mão de obra, serviços e capital, assim como a coordenação macroeconômica, deveriam ficar para uma etapa posterior.

57 Fortes resistências, sobretudo por parte do setor industrial argentino e de alguns segmentos industriais brasileiros explicáveis pela valorização da moeda argentina e pela conjuntura recessiva da economia brasileira. Nos anos de 1991 e 1992 foram registrados consideráveis superávits comerciais brasileiros no comércio com a Argentina. 
e automático ${ }^{58}$ para alcançar, em 31/12/1994, a tarifa zero. Manteve-se o cronograma de desgravação e avançou-se na aplicação do Regime de Adequação ${ }^{59}$.

Após as Cúpulas de Buenos Aires e Ouro Preto, a partir de dezembro de 1994, completou-se o quadro normativo para o funcionamento do MERCOSUL, com as seguintes características: a) Tarifa Externa Comum; b) Regime de Origem; c) Regime de Zonas Francas; d) Regime de Adequação; e) Restrições não tarifárias progressivamente harmonizadas; f) Incentivos às Exportações; $g$ ) Defesa da Concorrência com base no Regulamento Comum sobre Práticas Desleais de Comércio, pelo Estatuto sobre Defesa da Concorrência e pelo Regulamento Comum de Salvaguardas.

Nesse diapasão, recorda-se que a análise de ganhos e perdas derivados de um processo de integração ao se concentrar nos efeitos de uma união aduaneira, busca identificar os resultados de uma redução ou supressão das barreiras comerciais entre os países parceiros - mantidas as barreiras aos produtos oriundos de terceiros países - para os países intrabloco e para os demais países ${ }^{60}$.

Os indicadores para o bloco regional revelam um baixo grau de interação entre os processos produtivos, uma composição de comércio com forte componente de produtos de consumo final, e um grau elevado de dispersão no potencial econômico dos países partes, com desequilíbrios comerciais recorrentes ${ }^{61}$.

Em termos de MERCOSUL, o tema da fixação de paridades via moeda comum tem se feito presente desde os primeiros anos de vigência da Tarifa Externa Comum. Os partidários à proposta de unificação monetária indicam como argumentos favoráveis: a) o fortalecimento do bloco e o seu reconhecimento como uma potencia média, em que a soma das partes vale mais que o todo; $b$ ) maior estabilidade de preços, e por consequência maior estimulo aos investimentos, por meio de taxas

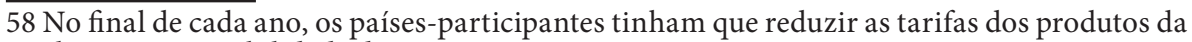
sua lista, sem possibilidade de renegociação.

59 Todos os produtos ficariam isentos de tarifas de importação no comércio intrabloco, exceto: 1) produtos sujeitos a regime de origem e 2) produtos listados no regime de adequação, aos quais se aplicaria tarifa decrescente, chegando à tarifa zero em quatro anos, no caso da Argentina e do Brasil ou em cinco anos, no caso do Paraguai e do Uruguai. BAUMANN, Renato. Op. cit.

60 Os primeiros estudos quanto aos benefícios de se explorar de forma sistemática o mercado de países vizinhos foram feitas por Adam Smith, em 1776, na sua obra clássica Riqueza das Nações. Smith reconhece que o país beneficiado com acesso a mercado externo tende a ganhar, e tanto mais, quanto mais prósperos forem os países vizinhos. "A nation that would enrich itself by foreign trade, is certainly most likely to do so when its neighbors are all rich, industrious, and commercial nations". SMITH, A. A riqueza das nações: investigação sobre sua natureza e suas causas (1776), Livro IV, Capítulo III. São Paulo: Editora Nova Cultural, 1990, p. 520 - Coleção Os Economistas. No contexto, cabe mencionar ainda, as análises feitas no início do século XX quanto às uniões aduaneiras e seus efeitos, por Cournot (1927), Wicksell (1934), Maurice Byé e Herbert Giersch e, sobretudo, as contribuições de Jacob Viner, 1950.

61 BAUMANN, 2013, 177. 
de juros menores; $c$ ) eliminação do risco cambial; $d$ ) eliminação dos custos de transação entre os países intrabloco ${ }^{62}$.

No mesmo diapasão, alguns estudos demonstraram a diminuição expressiva dos custos de transação e os prováveis ganhos para os países integrantes do MERCOSUL, especialmente para as economias menores do bloco, caso ocorresse à integração monetária. A partir da análise de informações detalhadas acerca dos custos de transação nas operações comerciais brasileiras com os países parceiros no MERCOSUL, verificou-se para o Brasil, um ganho da ordem de $0,9 \%$ do $\mathrm{PIB}^{63}$.

Por outro lado, autores mais críticos ou ceticistas à ideia de integração monetária enfatizam que, no MERCOSUL grande parte do trânsito de capitais tem lugar em operações com agentes externos à região, bem como a desregulamentação financeira no que se refere ao movimento internacional de capitais quanto à regulamentação interna dos mercados financeiros, ocorre em ritmos desiguais entre os parceiros. Ademais, existe acentuada assimetria no tratamento fiscal dos investidores estrangeiros entre os países intrabloco ${ }^{64}$.

Com vistas a verificar se os países do MERCOSUL atendem as condições requeridas à unificação monetária, Bichara, Cunha e Lélis, realizaram alguns testes empíricos a partir de dados coletados durante $o$ período de 1990 a 2004, concluíram os autores que, a região não satisfaz as condições básicas para a formação de área monetária comum, vez que não atende suficientemente às condições de transações comerciais regionais e de mão de obra significativas ${ }^{65}$.

Destarte, Kronberger a partir da realização de uma análise empírica detalhada quanto à factibilidade de uma integração monetária no MERCOSUL, pode concluir que a adoção dos critérios de Maastricht pelo bloco do Cone Sul revela-se no momento prematuro. Existem problemas vinculados à inflexibilidade salarial, inexistência de mecanismos opcionais de ajustes, como transferência fiscal ou mobilidade de mão de obra, portanto, abandonar o câmbio flexível seria demasiadamente custoso para os países do MERCOSUL ${ }^{66}$.

Análises mais recentes indicaram que, uma aproximação mais gradual e cautelosa entre os países do MERCOSUL seria o mais recomendável em termos de integração monetária ${ }^{67}$.

Atualmente, tem havido estímulos à realização de contratos

62 GIAMBIAGI, 1999, p.63-88.

63 CHAGAS; BAUMANN, 2007.

64 Tais argumentos são confrontados, segundo Giambiagi, com os avanços que se registraram no que se refere à elevação das transações entre os países do bloco, assim como à convergência nos parâmetros de endividamento público, sobretudo, da Argentina e do Brasil. GIAMBIAGI, P. Op. cit, p. 87; ABREU, 1997.

65 BICHARA; CUNHA; LELIS, 2008, p. 84-112.

66 KRONBERGER, 2002, 51.

67 Bresser e Holland a partir de seus estudos propõem uma aproximação gradual para as paridades de Brasil e Argentina. BRESSER; HOLLAND, 2009 apud BAUMANN, R. Op. cit. p. 98. 
comerciais em moedas nacionais dos países participantes, tal facilidade existe entre o Brasil e Argentina desde 2007, e a partir do ano de 2010 foi incluído o Uruguai, não obstante, os resultados por ora ainda estão aquém do esperado ${ }^{68}$. As considerações apresentadas no tocante à viabilidade de uma integração monetária, apesar de indicarem uma redução nos custos de transação, ao se permitir operações em moedas nacionais, são consideradas avanços, contudo, há necessidade de adequação.

A adoção de moeda comum pelos países intrabloco é ainda algo distante. Como demonstraram os estudos aqui analisados, faz-se necessária a redução da distância operacional entre os seus sistemas financeiros, o aumento da capacidade de resposta conjunta frente aos choques externos, bem como viabilizar a expansão dos recursos disponíveis para a provisão de liquidez e o financiamento de projetos.

Nessa análise há que se considerar ainda, o processo de desaceleração econômica, iniciado em 2011 e que se tem acentuado ao longo dos últimos anos. Em 2015, o Produto Interno Bruto (PIB) dos países da América Latina registrou contração de $0,4 \%$ resultando numa redução de $1,5 \%$ do $\mathrm{PIB}$ por habitante na região ${ }^{69}$.

A contração da atividade econômica regional foi consequência do menor dinamismo exibido pelas economias sul-americanas que a despeito de registrar uma expansão em 2014 de $0,6 \%$, registrou queda de $1,6 \%$ em 2015. As economias brasileira e venezuelana têm contribuído para o crescimento econômico negativo da região ${ }^{70}$.

Em 2016 é provável que o cenário instável da economia mundial dificuldades observadas na zona do euro, as crescentes incertezas sobre o futuro desempenho econômico da China, e em geral, das econômicas emergentes - afete o desenvolvimento da atividade econômica da região ${ }^{71}$.

As incertezas sobre o crescimento da economia mundial, se deve somar ao baixo crescimento do comércio, que em 2015 foi de 1,5\%, a taxa mais baixa depois da crise ocorrida entre 2007 e 2008. Neste contexto, há previsões não muito otimistas para 2016 em termos de intercâmbios para o conjunto dos países da América Latina e Caribe ${ }^{72}$.

No período 2014- 2015 a demanda interna desses, em especial, o consumo registrou desaceleração, igualmente houve retração dos setores industriais e de manufaturados no âmbito das economias regionais. Embora, se espere um leve crescimento positivo da economia regional na ordem de $0,2 \%$ superando a contração de $0,4 \%$ registrada em 2015.

68 Envolvendo não mais de $2 \%$ do comércio entre países. Essa facilidade ainda não é muito utilizada pelos agentes econômicos, o que sugere a necessidade de sua adequação.

69 CEPAL, 2015, p. 12.

70 CEPAL, 2015, p. 13.

71 Comissión Económica para América Latina y el Caribe. CEPAL. Panorama Económico y Social de la Comunidad de Estados Latinoamericanos y Caribeños, 2015. [acesso em 25 de mar. de 2016]. Disponível em: <http://cepal.org/es/publicaciones> pdf. .

72 CEPAL, 2015, p. 16. 
Quanto à diminuição do comércio intra-regional o primeiro semestre de 2015 registrou queda de $23 \%$ dos intercâmbios intrabloco MERCOSUL. O comércio entre a Argentina e o Brasil indicou retração de $17 \%$ para o mesmo período, e as compras recíprocas de produtos industriais, especialmente, bens de capital e bens duráveis apontaram redução de $25 \%{ }^{73}$.

Há que se considerar a partir dessa conclusão que o mercado regional tem peso distinto para cada um dos países participantes. As economias de menor dimensão apresentam dependência maior do comércio com seus pares, que absorve, no mais das vezes, mais de $50 \%$ do valor total exportado pelos parceiros menores ${ }^{74}$.

Desse modo, diante da ausência de homogeneidade de potencial econômico e de fundos compensatórios, o sucesso desse exercício integrativo fica na dependência de que as economias com maior potencial competitivo, ou seja, Argentina e Brasil contribuam para redução dos déficits comerciais externos dos seus parceiros. O MERCOSUL é um dos poucos exercícios integrativos cujo sócio maior é superavitário nas transações com as economias menores ${ }^{75}$.

Há necessidade ainda de elevar o nível de participação das exportações intrarregionais, tendo em vista que esta constitui apenas a quinta parte (por volta de 19,2\%) das exportações que tem como destino outros países de fora da região latino-americana. ${ }^{76}$ Ademais, as exportações centralizadas em produtos primários sempre representou um fator problemático na balança comercial. Todas as análises vinculadas aos exercícios integrativos existentes na América Latina e Caribe indicam como um objetivo prioritário, a integração produtiva regional ${ }^{77}$.

Tal cenário de instabilidade econômica certamente resultará em efeitos negativos sobre o MERCOSUL, acentuando ainda mais a diferença sub-regional dada à orientação produtiva e comercial das economias que compõem o bloco.

Desse modo, no que tange ao MERCOSUL pode-se concluir que, a despeito do viés recessivo que caracteriza o atual contexto da economia mundial, o processo de aproximação formal das economias

73 CEPAL, 2015, p. 15; p. 30.

74 BAUMANN, 2013, p. 181.

75 A situação do MERCOSUL revela o seguinte cenário, não apenas os parceiros maiores não proporcionam aos menores dinamismo por meio de fundos compensatórios, como ao longo do tempo somente aumenta a distancia de potencial econômico entre os países, BAUMANN, Op. cit. Ao se considerar os períodos entre 1990-2000 e 2001-2008 constata-se que as economias menores sequer puderam acompanhar o ritmo de produção ainda que nos setores básicos de suas economias, v.g., a produção de produtos agrícolas.

76 A liberalização do comercio intrarregional não tem estimulado suficientemente a diversificação produtiva e exportadora da região, que segue sinalizando uma grande dependência das exportações de produtos primários.

77 CEPAL, 2015, p. 28-30. 
contribuiu e tem contribuído para elevação considerável do volume regional transacionado desde sua criação no ano de 1991. Como visto, há efeitos positivo ou ganhos relativos em termos de aumento do grau de interação econômica, em alguns períodos mais e em outros menos. Ademais, houve avanços em relação à relevância relativa do mercado regional, notadamente, de 1991 a 1998, de 2004 a 2007 e entre os anos de 2011 a 2014.

Por fim, cabe aduzir que parte considerável dessa literatura dedicada à análise econômica da união aduaneira imperfeita ou parcial MERCOSUL, apontam unanimemente à necessidade de uma maior cooperação política associada a maior institucionalização como modo de fortalecer a credibilidade macroeconômica e avançar rumo ao nível de integração monetária. Diante dessa constatação, passar-se-á no item seguinte, à problematização da institucionalidade no processo de integração regional.

\section{A QUESTÃO DA (DES)NECESSIDADE DA INSTITUCIONALIDADE NO MERCOSUL}

A temática acerca da presença ou não de instituições capazes de estabelecer e fazer cumprir normas e políticas, a serem observadas pelos países participantes, mostra-se recorrente nas discussões sobre integração regional. Nos diversos exercícios regionais de integração, embora existam variados modelos de institucionalidade, pode-se afirmar que há dois modelos extremos, um modelo supranacional e outro modelo intergovernamental.

A análise comparativa entre estes modelos mostra-se essencial ao entendimento do modo de se proceder em processos de integração regional, assim como permite derivar lições variadas.

A União Europeia é o modelo de referência para os exercícios que optaram pela institucionalidade supranacional. A experiência europeia sempre foi marcada pela presença de instituições supranacionais para viabilizar a integração. Algumas instituições e mecanismos, tais como, o Conselho de Ministros, o Tribunal de Justiça das Comunidades Europeias e a tributo cobrado pela Comunidade Europeia do Carvão e do Aço (1950) antecedem a própria assinatura do Tratado de Roma (1957) que originou a Comunidade Europeia.

A experiềncia do MERCOSUL pode ser considerada como exemplo do modelo intergovernamental. Durante muitos anos, os países-membros optaram por um modelo cuja única instituição existente, era a Secretaria Administrativa, órgão, inclusive, sem competência normativa ou executiva.

Cabe mencionar ainda como exemplo do modelo intergovernamental, a experiência dos países nórdicos - Dinamarca, Finlândia, Islândia, Noruega e Suécia, cujo êxito do modelo de 
aproximação em formato intergovernamental, é menos questionado. As atuações comuns são paralelas, de tipo horizontal, e não impostas por burocracias supranacionais. Para este modelo de integração o formato de aproximação e a vontade política dos países parceiros têm se mostrado mais relevantes.

Um aspecto interessante a ser evidenciado no tocante ao MERCOSUL, e que o diferencia de outros exercícios de integração intergovernamental, tais como, NAFTA e outros grupos de países, é que apenas o MERCOSUL adota um modelo intergovernamental com a inclusão da dimensão política no processo negociador. Como visto, o bloco regional do Cone Sul reúne um grande número de Grupos de Trabalho dedicados a assuntos que não se restringem a setores econômicos, bem como há foro de consulta e concertação política e reuniões sistemáticas de autoridades para discussões atinentes aos direitos humanos.

Não há consenso entre as perspectivas que consideram imprescindíveis à adoção de instituições supranacionais. Algumas visões são taxativas quanto à necessidade de se adotar instituições supranacionais. Uma das razões para tanto, é que o modelo intergovernamental tende a degenerar em transações bilaterais, com ganhos somente de curto prazo $^{78}$. Outras percepções remondam alguma cautela quanto à criação de instituições supranacionais, e recomendam a combinação de distintos mecanismos em termos de obrigações e delegação ${ }^{79}$.

Inclusive, as instituições regionais devem evoluir com o passar do tempo, em razão das condições objetivas, da forma que se espera que atuem no processo de integração e do modo como responde a novas demandas, o que pode demandar ajustes no próprio delineamento institucional.

No que tange ao MERCOSUL, o bloco optou por um modelo considerado mais flexível, posto que, permitiu o ajuste de modo expressivo do formato negociador em 1990, a adoção de mecanismos de adaptação nos primeiros anos de vigência da TEC, assim como possibilitou acomodar algumas disputas entre os países-membros.

Entretanto, frequentemente a opção intergovernamental adotada pelo MERCOSUL é alvo de críticas, dentre as mais comuns, está à necessidade de se delinear mecanismos mais eficientes para a solução de disputas, a despeito dos existentes até momento face o aumento no volume de transações entre os países, bem como apenas um percentual bastante reduzido das normas acordadas são efetivamente colocadas em prática ${ }^{80}$.

Assim, mesmo em um exercício predominantemente intergovernamental parece haver a necessidade de mecanismos e

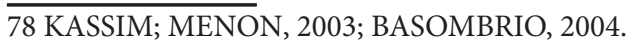

79 BEST, Eduard. Supranational institutions and regional integration. 2005. [acesso em: 28 mar. 2016]. Disponível em: <http://www.eclalc.cl/cgi-bin/getProd.asp?xml=/brasil/noticias/ paginas/2/22962/P22962.XML\&XSL=/brasil/tpl/p18f.xsl\&base=/brasil/tpl/top=bottom.xsl> 80 LEÓN LI, 2011, p. 68. 
normas supranacionais com vistas a assegurar a sua observância e o seu cumprimento. É imprescindível credibilidade e vontade por parte do órgão sancionador para reprimir os países-membros não cumpridores. ${ }^{81}$

Não se mostra evidente, contudo, se é preferível um processo mais centralizado ou a preservação de decisões partilhadas, entre os governos participantes. Tampouco, é claro que a existência de instituições supranacionais seja uma condição imprescindível e necessária para o sucesso do processo de integração regional.

Cumpre ressaltar que a reflexão sobre institucionalidade compreende algumas dimensões que transcendem a existência ou não de organismos e agências. Conforme destaca Eduard Best, o nível supranacional só faz sentido como parte de um conjunto de governança com variados níveis, as instituições devem ser compreendidas como um sistema normativo de regras e valores aceitos por uma ordem determinada, podendo estar ou não incorporado em determinadas organizações ${ }^{82}$.

Tal ideia é importante na medida em que problematiza a relação entre a questão da soberania e a supranacionalidade normativa. A experiência da União Europeia, neste contexto, constitui um modo específico de os Estados-membros assumirem sua própria soberania, por meio de processos decisórios comuns, há uma interação entre governos nacionais e instituições regionais.

Ressalta-se a necessidade de se ter presente a distinção entre perda de níveis de liberdade no que se refere à soberania - o que ocorre quando se delega poder decisório a instâncias supranacionais - e a opção de "compartilhar soberanias" que acontece quando os Estados preservam o seu poder decisório.

A supranacionalidade implica a presença de instituições supranacionais dotadas de competência para expedir normas dotadas de operatividade, ou efeito direto, e a supremacia ou proeminência em relação ao direito nacional. De outra feita, um processo de integração com órgãos intergovernamentais implica, a priori, menos restrições à soberania dos Estados que um processo de integração dotado de instituições supranacionais. Entretanto, cabe destacar que, isso se refere a uma questão de graduação - perdas de graus de liberdade - e não presença ou ausência de limitações ${ }^{83}$.

O papel do Poder Judiciário nacional também se revela essencial para o bom funcionamento de um sistema regional. Quanto maior seu envolvimento, tanto maior a probabilidade de que as normas comunitárias sejam observadas. Faz-se necessária o delineamento de mecanismos supranacionais capazes de solucionar as controvérsias e

81 Cf. LEÓN LI, Jaime Martín. Regional Process in South American: Analysis of institutions and policies of regional integration under the EU Framework. Hamburg: Diplomica Verlag $\mathrm{GmbH}, 2011$.

82 BEST, 2005, p. 68.

83 BOGGIANO, 1994, p. 102. 
com capacidade de promover estabilização adequada.

Destaca-se a importância dos acordos serem críveis, posto que a existência de instâncias supranacionais capazes de expedir normas jurídicas de caráter vinculante para os Estados e os indivíduos tem implicações importantes. Além disso, o sistema supranacional pode diminuir os custos de transação ao institucionalizar os processos de negociação.

Geralmente, a delegação de poder decisório a instâncias supranacionais das matérias originalmente tratadas pelo Poder Executivo nacional são mais facilmente transferidas ao nível regional que as matérias que são da competência do Poder Legislativo.

O sistema do MERCOSUL não é supranacional, mas intergovernamental. Disso resulta que as decisões no âmbito de seus órgãos são tomadas pelos Chefes dos Estados-membros ou por autoridades com competência para tanto. O Tratado de Assunção e os Protocolos Adicionais, ao contrário dos Tratados da União Europeia, não outorgam a qualquer dos órgãos do MERCOSUL a faculdade de expedir, de modo autônomo, normas de conteúdo geral ou particular e aplicação direta aos particulares.

O caráter vinculante estabelecido no art. 42 do Protocolo de Ouro Preto às normas emanadas do Conselho do Mercado Comum, Grupo Mercado Comum e Comissão de Comércio diz respeito aos Estados-membros. Por ora, para que as normas do direito derivado sejam exigíveis com relação aos particulares, os Estados Partes devem incorporá-las as respectivas legislações nacionais.

O sistema de solução de controvérsias no MERCOSUL, consubstanciado nos Protocolos de Brasília e Olivos, como visto no item 1, é inspirado pelo Documento Técnico 319 do Banco Mundial, cujo teor recomenda a reformulação do Judiciário na América Latina, bem como sublinha a necessidade de criação dos Alternative Dispute Resolution (ADRs) ou Mecanismos Extrajudiciais de Solução de Controvérsias (MESCs).

Neste diapasão, cabe evidenciar que os órgãos regionais deverão primar, tanto em relação aos mecanismos de produção normativa, quanto ao que tange aos mecanismos de resolução de conflitos, pela maior participação efetiva dos agentes sociais. Apesar de os grandes desafios estarem nas questões comerciais, como por exemplo, as já mencionadas clausulas de salvaguarda e nas medidas de proteção não tarifárias ${ }^{84}$, a participação social é deveras importante para o futuro do bloco.

Os processos de integração regional consolidam-se melhor quanto maior for o respaldo dos cidadãos. Tal respaldo é proporcional à percepção de custo e beneficio que os nacionais dos países envolvidos conseguem ter, no que tange ao exercício integrativo. Tal percepção está

84 Uma possível solução seria seguir o estabelecido nas normas da Organização Mundial do Comércio (OMC) complementando-as com normas específicas. 
vinculada do modo estrito à noção de delegação de poder por parte de cada individuo a uma burocracia regional ${ }^{85}$.

Nesse contexto, o Parlamento do MERCOSUL constituiria um meio eficaz de viabilizar resultados no sentido de uma maior participação social com vistas a equacionar os problemas do "déficit democrático" e do "déficit do compromisso". Apesar do avanço que representou a criação do Parlamento em substituição a Comissão Parlamentar Conjunta, permanece como já visto, o seu caráter de órgão consultivo ${ }^{86}$.

Destaca-se que um dos propósitos do Parlamento explicitado no Protocolo Constitutivo do Parlamento MERCOSUL, é garantir a participação dos atores da sociedade civil no processo de integração. Visando a integração ao Parlamento o documento estabelece o critério de representação cidadã, bem como a eleição dos Parlamentares do MERCOSUL ser dará por meio de sufrágio direto, universal e secreto pelos cidadãos dos respectivos Estados Partes ${ }^{87}$.

A ausência de uma institucionalização mínima é, por certo, um obstáculo ao bom desenvolvimento do MERCOSUL. Nesse sentido, com o passar dos anos da evolução do processo integrativo, foi ficando evidente a necessidade de se estabelecer acordos macroeconômicos, mecanismos jurídicos de solução de controvérsias, corpo técnico próprio voltado a elaborar propostas e soluções que visam à consolidação regional ao invés de instâncias exclusivamente intergovernamentais, suficientes a permitir os avanços esperados com a integração ${ }^{88}$.

Com vistas a melhor compreender o funcionamento do MERCOSUL é preciso levar em consideração as relações de poder existentes intrabloco. Isso em grande medida condiciona os seus avanços ou recuos. Não se pode ver o MERCOSUL como um bloco coeso, os países que o compõem possuem diferenças em termos políticos, culturais e econômicos. Tal questão é reforçada face à ausência de órgãos supranacionais capazes de tomar decisões desvinculadas dos estritos interesses dos Estados-membros ${ }^{89}$.

O principal desafio econômico para a região parece ser promover a transformação produtiva, mas com equidade. $\mathrm{O}$ caminho a ser trilhado para um desenvolvimento regional eficaz pode estar no fomento à inversão do crescimento no setor externo por meio da canalização dessa inversão e crescimento aos produtos internos de maior valor agregado, evitando repetir a experiência de várias economias latino-americanas

85 BAUMANN, 2013, p. 153.

86 Cf. STRAUS, Flávio Augusto Saraiva. Soberania e integração latino-americana - uma perspectiva constitucional do MERCOSUL. Rio de Janeiro: Forense, 2002.

87 Art. 5 ${ }^{\circ}$, item 01 e 02 do Protocolo Constitutivo do Parlamento do MERCOSUL. MERCOSUL. Protocolo Constitutivo do Parlamento MERCOSUL. Disponível em: < http:// www.parlamentodelmercosur.org/innovaportal/v/7555/2/parlasur/protocolo-constitutivodo-parlamento-do-mercosul.html> Acesso em 28 mar. 2016.

88 CAETANO, 2011.

89 FREITAS JR, 2006, p. 310. 
ao longo dos séculos, de aplicá-la prioritariamente em bens primários.

Evidenciam-se, como problemas emergentes do modelo exportador primário, os efeitos negativos sobre a ecologia, o enfraquecimento da ação coletiva e do movimento sindical, a redução da capacidade de negociação, decorrente da reestruturação produtiva reforçada pela globalização.

Embora algumas economias do bloco tenham dados alguns sinais de recuperação, são alarmantes a sua incapacidade de alcançar verdadeiros estados de bem-estar. Ao lado da estabilização econômica, reeditam-se os velhos e graves dilemas, pobreza, distribuição regressiva de renda, elevação do dualismo entre setores minoritários que se agregam à globalização e sua possiblidades e setores que vão sendo marginalizados do desenvolvimento ${ }^{90}$.

Por conseguinte, subsiste a necessidade de analise dos efeitos negativos ou disfuncionais neste caminho de êxito econômico e de redução da ideia social a um só componente, ou seja, o "mercado". O fenômeno de exclusão social evidenciou a relevância de desenvolvimento sistêmico ou político com vistas ao acesso equitativo aos bens e oportunidades.

Assim, em conjunto com ajuste econômico faz-se necessário delinear-se um ajuste politico e social. Os consensos sociais e políticos sobre o que é possível, desejável e imprescindível aos países componentes e ao próprio bloco MERCOSUL. Não se mostra verdadeira a premissa que as forças do mercado sejam a única alternativa ao desenvolvimento, também as forças políticas dos Estados e as demandas da sociedade civil são componentes que devem ser considerados nos acordos que realizam os agentes econômicos.

A fragilidade dos Estados latino-americanos, em geral, revela-se em algumas constatações, tais como, a debilidade dos atores sociais, quer seja das sociedades civis ou mesmos seus Estados, em demandar, exigir, controlar e se opor ao poder econômico; a debilidade das instituições políticas egressas de um ciclo autoritário quanto ao aprofundamento democrático; a apatia ou retraimento dos indivíduos frente supremacia do econômico sobre o político-social, atribuindo-se aos círculos de governos e de peritos ou aos grupos econômicos o papel social nas decisões ${ }^{11}$.

A integração econômica, objeto do MERCOSUL, além de constituir uma livre circulação de bens e serviços, isenta de barreiras tarifárias e não tarifárias, deve também perseguir o bem-estar social, objetivo inclusive previsto no Tratado de Assunção, por meio de uma eficaz harmonização das politicas macroeconômicas, com equalização tributária, estabilização de preços, com certa homogeneidade entre as econômicas dos países-membros. Nessa esteira, está reservada ao Subgrupo de Trabalho 11, com a sua nota tripartite, a importante missão

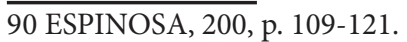

91 TEIXEIRA FILHO, 1996, p. 441-469. 
de equilibrar os desejáveis ganhos econômicos com os imprescindíveis avanços sociais.

O caminho a trilhar pelo bloco regional do Cone Sul acha-se traçado, até que se efetivem a União Aduaneira perfeita e o Mercado Comum. Consumadas, então, essas fases deverá acontecer uma coordenação politica institucionalizada com fins de se atingir uma união econômica ampliada, com moeda única e banco central, a coordenação da segurança comum e a implementação dos direitos individuais e coletivos ${ }^{92}$.

Nesse ínterim, alguns passos rumo à concretização da agenda integrativa já foram dados, em termos gerais, citam-se, o processo de convergência das ultimas exceções à Tarifa Externa Comum do MERCOSUL, a conclusão das negociações hemisféricas para a conformação da ALCA, assim como a assinatura de um Acordo-quadro entre o MERCOSUL e a União Europeia com vistas a promover uma área de livre comércio no espaço transatlântico. Destaca-se ainda o Acordo de Livre Comércio com Israel (2007), o marco de Cooperação Econômica com o Conselho de Cooperação do Golfo (2005), e o Acordo Preferencial de Comércio firmado com a União Aduaneira da África do Sul (2008).

Com o surgimento da UNASUL (2008) cresceu o debate em torno da permanência do MERCOSUL, tendo em vista a sua amplitude, porquanto àquele abarca todos os países do subcontinente, no qual este se inclui. Não obstante, tem havido entendimento no que tange a convivência de ambos os blocos, os quais, em vez de excluir-se, complementam-se na complexa tarefa de integração.

Pode-se afirmar que, sobretudo no setor da economia, o MERCOSUL tem obtido resultados favoráveis para os respectivos países participantes. Também há desenvolvimento, apesar de lento e gradual em áreas sociais, por meio da criação de redes de solidariedade. Na área educacional buscase por meio de processos de facilitação de circulação de docentes e discentes e reconhecimento de diplomas. No âmbito da saúde, tem-se avançado no trabalho na área de genéricos e do controle de endemias.

Assim, pode-se concluir que independente do modelo institucional a ser adotado, quer supranacional ou intergovernamental, é fundamental que ele reflita as estruturas e as demandas das sociedades envolvidas, as instituições devem ser capazes de se adaptarem às novas conjunturas.

Nesse contexto, o diagnóstico da atual crise no processo de integração do MERCOSUL indica como causa básica ao êxito de seu avanço, o distanciamento do aspecto social da integração, o menosprezo do objetivo da justiça social assinalado no preâmbulo do Tratado de Assunção e a negligencia no trato de questões essenciais ao pleno exercício da cidadania.

Frisa-se que a configuração institucional do MERCOSUL permanece provisória, e sua estruturação definitiva ainda tem pontos

92 CHIARELLI, 1997, p. 75-83. 
cruciais de indefinição a serem superados. Por conseguinte, com a persistência das omissões, equívocos e contradições de seu projeto, o MERCOSUL tenderá a sucumbir.

Todavia, o processo de integração necessita ser revigorado por meio do direcionamento no sentido do ajuste econômico, politico e social comunitário ordenado, da plena democratização e principalmente tendo o ser humano como centro e destinatário das medidas tomadas e concretizadas.

\section{CONCLUSÃO}

O presente artigo pretendeu desenvolver uma análise de custos e benefícios após os 25 anos da assinatura do Tratado de Assunção, o qual instituiu o Mercado Comum do Sul - MERCOSUL.

Buscou-se evidenciar a partir de uma historiografia das conjunturas do bloco regional do Cone Sul, que este é resultado de um exercício integrativo iniciado por meio da aproximação de dois países historicamente adversários, que após o movimento de independência frente às respectivas Metrópoles, trasladaram à América a animosidade histórica existente na Península Ibérica entre Espanha e Portugal. Não obstante, a superação de anos de regimes autoritários e ditatoriais com a entrada em cena da democracia - ainda que incompleta - ensejou a aproximação entre Argentina e Brasil por meio de uma nova estratégia hegemônica regional conjunta de integração.

Procurou-se destacar a abordagem em voga quanto à análise dos processos integrativos, ou seja, a abordagem focada estritamente na "ética de resultados". Mencionados modelos, como visto, pautam-se em indagações relacionadas aos efeitos, isto é, em que medida determinado modelo pode ser eficiente, ou se são suportáveis os possíveis custos e efeitos indesejados de sua implementação, por conseguinte, considera que a integração tem valor à medida que obtém resultados, ou pelo que se alcança.

Destacou-se que tais resultados, tanto positivos quanto negativos estão a depender do modelo e do nível de exercício integrativo adotados. No que tange à atual fase de integração do MERCOSUL, ou seja, de união aduaneira imperfeita ou parcial, pôde-se notar a partir das inferências dos estudos aqui apresentados, um balanço com saldo positivo a despeito dos dilemas, crises e estagnações cujo bloco experimentou e que, de certo modo, ainda experimenta.

Evidenciou-se que a assinatura de acordos de preferência comerciais entre países vizinhos está vinculada aos benefícios e ganhos que podem resultar de relações econômicas mais intensas, posto que, custos de transação menores estimulam os fluxos de comércio e o investimento, consequentemente, a expansão de mercados permite ganhos associados à absorção de economias de escala. 
Ainda, a maior intensidade comercial regional pode estimular o processo de industrialização e promover ganhos de eficiência. Com vistas, a minimizar as desigualdades estruturais e econômicas entre os países, as propostas aqui analisadas, indicaram a necessidade de promover mecanismos de distribuição intrarregional dos superávits comerciais.

Pode-se aduzir que várias das questões enfrentadas pelo bloco regional em comento, especialmente, no que tange ao alcance de suas finalidades não resultam apenas das constantes instabilidades macroeconômicas que atingem os países membros, considerados "hegemônicos", notadamente, a Argentina e o Brasil. Encontram-se vinculadas às fragilidades do modelo intergovernamental adotado pelo bloco regional e também às suas deficiências institucionais.

Nessa esteira, também se constatou que, a falta de verdadeiras instituições supranacionais em sua estrutura atual não significa que o MERCOSUL deva seguir ou importar acriticamente o modelo aplicado em outros blocos de matiz exclusivamente ou não econômico.

Entre os custos do modelo intergovernamental, vislumbrouse a questão de que os acordos firmados no âmbito do MERCOSUL encontram um grau de aplicação considerado relativamente baixo, não obstante a sua flexibilidade face à ausência da rigidez institucional tenha permitido ajustes no processo negociador. Assim, as instituições regionais devem ser delineadas com vistas a resolver conflitos entre Estados e também entre agentes dos países participantes, e entre eles e outros Estados.

Ademais, evidenciou que a opção regional não é isenta de desafios e dificuldades, demandando ações em caráter bem mais incisivo do que o que se tem observado até aqui, no caso do MERCOSUL. Existem no âmbito do bloco regional alguns desafios evidentes, tais quais, promover crescimento econômico regional equilibrado, superar as barreiras de infraestruturas inadequadas; delinear a criação da cooperação monetária e financeira; alterar a lógica de negociação por meio do aumento na aposta da complementaridade produtiva e identificar uma nova racionalidade em defesa da integração regional.

Neste diapasão, o presente artigo sustentou que não se trata apenas da busca de complementaridade produtiva, outro aspecto importante a ser considerado é a superação das barreiras ideológicas e políticas ao processo de integração.

A condição elementar para superar as barreiras ao regionalismo cinge-se a compreender a integração como um jogo de soma positiva, isto é, que todos os participantes - Estados, agentes econômicos e cidadãos - identifiquem mais vantagens em participar do exercício integrativo do que em buscar alternativas isoladas. Como visto, uma das condições básicas para que as negociações reflitam os interesses dos indivíduos e que o que for pactuado venha a ser internalizado pelas ordens jurídicas 
internas dos países envolvidos, aumentado o grau de envolvimento dos Poderes Legislativo e Judiciário.

Efetivamente houve incremento comercial e os países-membros do bloco do Cone Sul têm envidado esforços no sentido de solucionar outros problemas que, transcendem o mero incremento econômicocomercial, atinente às searas política, social, ambiental e cultural. Nessa esteira, argumentou-se que MERCOSUL possui finalidades de caráter pluridimensional, tendo em vista que é dotado de ambições de cunho político, social, ambiental e cultural que transcendem o estrito fator econômico-mercantil.

Revela-se deveras importante analisar os avanços e retrocessos do MERCOSUL a partir de suas vicissitudes e peculiaridades, sob a ótica do "possível". O processo de integração é como o próprio nome diz, processo, não se deve compreendê-lo a partir de imagens estáticas de períodos específicos, mas como trajetórias de longo prazo.

\section{REFERÊNCIAS BIBLIOGRÁFICAS}

ALMEIDA, Paulo Roberto de. MERCOSUL: Fundamentos e Perspectivas. São Paulo: LTr, 1998.

ARBUET-VIGNALI, Heber. Claves jurídicas de la Integración (En los sistemas del Mercosur y la Unión Europea). Buenos Aires: RubinzalCulzoni, 2004.

BASOMBRIO, I. Integracion Andina: instituciones y derecho comunitário. 2004. [acesso em 28 mar. 2016]. Disponível em: $<$ http:// www.eclac.cl/cgin-bin/getprod.pdf>

BAUMANN, Renato. Integração Regional: Teoria e Experiencia LatinoAmericana. Rio de Janeiro: LTC, 2013.

BHAGWATI, J. (ed.). Selected readings in internation trade. Massachussetts, C.A: The MIT Press, 1991.

BEST, Eduard. Supranational institutions and regional integration. 2005. [acesso em 28 mar. 2016]. Disponível em: <http://www.eclalc. $\mathrm{cl} /$ cgibin/getProd.asp? $\mathrm{xml}=/ \mathrm{brasil} /$ noticias/paginas/2/22962/P22962. XML\&XSL=/brasil/tpl/p18f.xsl\&base=/brasil/tpl/top $>$

BICHARA, Julimar; CUNHA, André.; LÉLIS, Marcos Tadeu. "Integración monetária y financeira em América del Sur y en Asia". Latin American research review. 2008, vol 43, n 1, p. 84-112.

BIOCCA, Stella Maris. Claves político-juridicas para la integración latino-americana. Buenos Aires: Zavalia, 2001.

BOGGIANO, Antonio. Hacia el Desarrollo Comunitário del MERCOSUR desde la experiencia de la Union Europea. Coimbra: Gráfica de Coimbra, 1994. 
BOUZAS, Roberto; SOLTZ, Hérnan. Instituciones y Mecanismos de Decisión en Procesos de Integración Asimétricos: o caso MERCOSUR. Hamburgo: Universidade de Hamburgo. Institut fur IberoamericaKunde, 2002.

CASELLA, Paulo Borba; ARAÚJO, Nadia de (ed.). Integração jurídica Interamericana - as Convenções Interamericanas de Direito Privado (CIDIPs) e o direito brasileiro. São Paulo: LTr, 1998.

CASTILLO, Santiago Pérez de. O direito de greve. São Paulo: LTr, 1994.

CAETANO, Gerardo (ed.). MERCOSUR: 20 años. Montevideo: Centro de Formación para la Integración Regional(CEFIR), 2011.

CEPAL. Comissión Económica para América Latina y el Caribe. Panorama Económico y Social de la Comunidad de Estados Latinoamericanos y Caribeños, 2015. [Acesso em 25 de mar. de 2016]. Disponível em: $<$ http://cepal.org/es/publicaciones $>$ pdf $>$

DEVLIN, R.; GIORDANO, Paul. The old and new regionalismo: benefits, costs and implications for the FTAA. Cambrige, MA: Harvard University Press, 2004.

ESPIELL, Héctor Gross. "Naturaleza jurídica del Tratado de Asunción y de sus protocolos". In: CHIARELLI, Carlos Alberto Gomes (ed.). Temas de Integração com enfoques no MERCOSUL. São Paulo: LTr, 199.

FREITAS JÚNIOR, Antonio de Jesus da Rocha. Manual do MERCOSUL: Globalização e Integração Regional. São Paulo: BH Editora, 2006.

$\mathrm{FLORENCIO}_{2}$ S.A.L.; ARAÚJO, E. H. F. Mercosul Hoje. São Paulo: Editora Alfa-Ómega, 1996.

GIAMBIAGI, F. "MERCOSUR: porqué la unificación monetária tiene sentido a largo plazo?". Integracion \& Comercio. 1999, vol 3, n 9.

GINESTA, J. El Mercosur y su contexto regional e internacional. Porto Alegre: editora Universidade/UFRGS, 1999.

GONZALEZ-OLDEKOP, Florencia. La integración y sus Instituciones. Buenos Aires: Ciudad Argentina, 1997.

HOBSBAWN, Eric. Nações e nacionalismo desde 1780. São Paulo: Paz e Terra, 1990.

KASSIM, H.; MENON, A. "European integration since the 1990s: member states and the European Commission". In: Arena Seminar (Oslo, 2003). Oslo University of Oslo, 2003.

KRUGMAN, Paul; VENABLES, A. Integration, specialization and adjustment. European Economic Review, v. 40, p. 959-967, 1996.

LIPSEY, Richard G. "The theory of Customs Unions: Trade Diversion and Welfare". Economica, New Series, 1957, vol 24, n 93. 
MARIÁTEGUI, José Carlos. Siete ensayos de interpretación de la realidad peruana. Caracas: Fundación Biblioteca Ayacucho, 2007.

MELLO, Celso D. de Albuquerque. Curso de direito internacional público. Rio de Janeiro: Renovar, 2000, vol 1.

MERCOSUL. Protocolo Constitutivo do Parlamento MERCOSUL. [acesso em 28 mar. 2016.] Disponível em: <http://www.parlamentodelmercosur. org/innovaportal/v/7555/2/parlasur/protocolo-constitutivo-doparlamento-do-mercosul.html $>$

MERCOSUL. Protocolo de Ouro Preto, assinado em Ouro Preto, Brasil, em 17 de dezembro de 1994.

MONIZ BANDEIRA, L. A. Argentina, Brasil y Estados Unidos. De la Triple Alianza al MERCOSUR. Buenos Aires: editorial norma, 2004.

PIZZOLO, Calogero. Globalización e integración - Ensayo de uma Teoría General. Buenos Aires: Ediar, 2002.

SÁNCHEZ, Alberto M. Derecho de la integración - um recorrido múltiple por las experiencias de la Union Europea y del MERCOSUR. Buenos Aires: RAP, 2004.

SANTOS, P.F. Pereira dos. União monetária: aspectos teóricos, experiências históricas e as perspectivas de implementação de uma moeda única no MERCOSUL. Brasília: UnB, 1999.

SMITH, A. A riqueza das nações: investigação sobre sua natureza e suas causas. São Paulo: Editora Nova Cultural, 1990.

STRAUS, Flávio Augusto Saraiva. Soberania e integracão latinoamericana - uma perspectiva constitucional do MERCOSUL. Rio de Janeiro: Forense, 2002.

VINER, Jacob. The custos union issue. New York: Carnegie Endowment for Internation Peace, 1950.

ZEA, Leopoldo. Latinoamérica encrucijada de culturas. México: Fondo de Cultura Económico, 1999. 